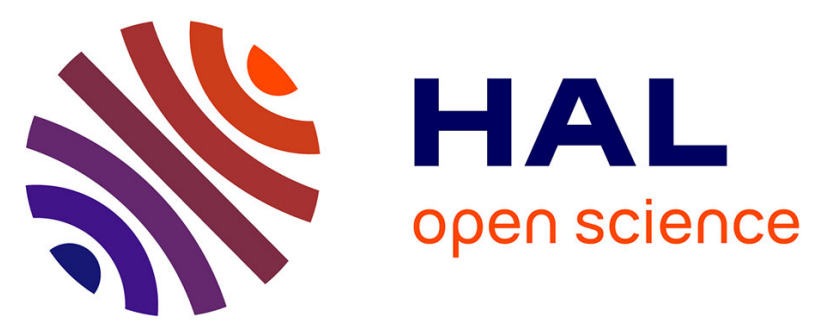

\title{
Cis and trans-bis(tetrathiafulvalene-acetylide) platinum(II) complexes: syntheses, crystal structures, and influence of the ancillary ligands on their electronic properties.
}

Antoine Vacher, Frédéric Barrière, Franck Camerel, Jean-François Bergamini, Thierry Roisnel, Dominique Lorcy

\section{To cite this version:}

Antoine Vacher, Frédéric Barrière, Franck Camerel, Jean-François Bergamini, Thierry Roisnel, et al.. Cis and trans-bis(tetrathiafulvalene-acetylide) platinum(II) complexes: syntheses, crystal structures, and influence of the ancillary ligands on their electronic properties.. Dalton Transactions, 2013, 42 (2), pp.383-94. 10.1039/c2dt31686b . hal-00808976

\section{HAL Id: hal-00808976 https://hal.science/hal-00808976}

Submitted on 15 Jul 2013

HAL is a multi-disciplinary open access archive for the deposit and dissemination of scientific research documents, whether they are published or not. The documents may come from teaching and research institutions in France or abroad, or from public or private research centers.
L'archive ouverte pluridisciplinaire HAL, est destinée au dépôt et à la diffusion de documents scientifiques de niveau recherche, publiés ou non, émanant des établissements d'enseignement et de recherche français ou étrangers, des laboratoires publics ou privés. 


\title{
Dalton

\section{Cis and trans-bis(tetrathiafulvalene-acetylide) platinum(II) complexes: syntheses, crystal structures, and influence of the ancillary ligands on their electronic properties $t$}

\author{
Antoine Vacher, Frédéric Barrière, Franck Camerel, ${ }^{*}$ Jean-François Bergamini, \\ Thierry Roisnel and Dominique Lorcy*
}

A series of four platinum(॥) complexes bearing two tetrathiafulvalene acetylide ligands coordinated

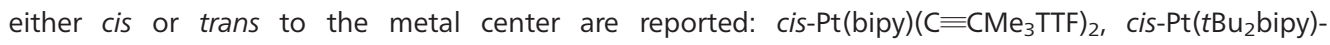
$\left(\mathrm{C} \equiv \mathrm{CMe}_{3} \mathrm{TTF}\right)_{2}$, cis-Pt(dppe)( $\left.\mathrm{C} \equiv \mathrm{CMe}_{3} \mathrm{TTF}\right)_{2}$ and trans-Pt $\left(\mathrm{PPh}_{3}\right)_{2}\left(\mathrm{C} \equiv \mathrm{CMe}_{3} \mathrm{TTF}\right)_{2}$. The $\mathrm{X}$-ray diffraction studies of the four complexes are reported and discussed. The electrochemical investigations carried out by cyclic voltammetry (CV) and differential pulse voltammetry (DPV) evidenced different redox behavior as a function of the ancillary ligand. Only for the cis-Pt(dppe)( $\left.\mathrm{C} \equiv \mathrm{CMe}_{3} \mathrm{TTF}\right)_{2}$ complex is the first oxidation wave resolved $(\Delta E=70 \mathrm{mV}$ ) into two one-electron processes. Spectroelectrochemical investigations performed on the four complexes did not evidence any electronic interactions between the two organic electrophores. The splitting of the first oxidation wave observed in cis- $\mathrm{Pt}(\mathrm{dppe})\left(\mathrm{C} \equiv \mathrm{CMe}_{3} \mathrm{TTF}\right)_{2}$ is mainly explained by the non-equivalence of the two TTF moieties induced by the geometrical constraint imposed by the ancillary dppe ligand as found by density functional theory calculations.

Received 26th July 2012,

Accepted 21st September 2012

DOI: $10.1039 / \mathrm{c} 2 \mathrm{dt} 31686 \mathrm{~b}$

www.rsc.org/dalton

\section{Introduction}

This last decade, the coordination chemistry of tetrathiafulvalene (TTF) derivatives has focused a lot of attention towards the elaboration of electroactive transition metal complexes with original electronic properties due to interplay between the TTF and the electron density on the metal. ${ }^{1-5}$ To study these interactions between the TTF moiety and the metal center, another approach has been recently developed which relies on organometallic chemistry and on the connection of a TTF to the metal center through a conjugated carbon chain. To date only four examples of such hybrid organic-inorganic building blocks have been reported, and all of them involve one or two TTF acetylide ligands coordinated to a metal center (Chart 1). Interestingly, electronic coupling was evidenced between the TTF and the metal electrophore within trans- $\mathrm{RuCl}\left(\mathrm{C} \equiv \mathrm{CMe}_{3} \mathrm{TTF}\right)(\mathrm{dppe})_{2}{ }^{6}$ and

\footnotetext{
Institut des Sciences Chimiques de Rennes, UMR 6226 CNRS-Université de Rennes 1, Campus de Beaulieu, Bâtiment 10A, 35042 Rennes, France.

E-mail: franck.camerel@univ-rennes1.fr, dominique.lorcy@univ-rennes1.fr $\dagger$ Electronic supplementary information (ESI) available: Computational details and crystallographic data of new compounds. CCDC 816625-816628. For ESI and crystallographic data in CIF or other electronic format see DOI: $10.1039 / \mathrm{c} 2 \mathrm{dt} 31686 \mathrm{~b}$
}

$\mathrm{Cp}^{*}(\mathrm{dppe}) \mathrm{Fe}\left(\mathrm{C} \equiv \mathrm{CMe}_{3} \mathrm{TTF}\right)^{7}$ with the strength of the coupling depending on the nature of the metal. Interplay between the two TTFs along the linker has also been evidenced in the trans $-\mathrm{Ru}\left(\mathrm{C} \equiv \mathrm{CMe}_{3} \mathrm{TTF}\right)_{2}(\mathrm{dppe})_{2}$ through the observation of multistage redox behavior whereas the TTF itself exhibits two reversible one-electron processes. $^{8}$ It is worth mentioning that the use of an acetylide-Cr-acetylide organometallic bridge does not allow an electrochemical detection of interplay between the two TTFs within [CrCyclam(C $\equiv$ CEDTMeTTF $\left.)_{2}\right]_{\text {OTf. }}{ }^{9}$ Nevertheless, electrochemical oxidations of this complex lead to two salts where mixed-valence TTF units were obtained. Among the various bisacetylide metal complexes, those involving a platinum center with various ancillary ligands have also proved their strong propensity to allow electronic interaction by connecting either organic or organometallic electrophores. ${ }^{10-12}$

In this context, the aim of this work is to investigate the electronic properties of mononuclear platinum complexes containing two TTF acetylide ligands and either diimine or phosphine as ancillary ligands, namely triphenylphosphine, 1,2-bis(diphenylphosphino)ethane (dppe), 2,2'-dipyridyl (bipy) or 4,4'-di-tert-butyl-2,2'-dipyridyl $\left(t \mathrm{Bu}_{2}\right.$ bipy $)$. Herein, the synthesis, characterization and properties of a series of $\mathrm{Pt}(\mathrm{II}) \mathrm{com}^{-}$ plexes bearing two monodentate TTF acetylide ligands are reported. 


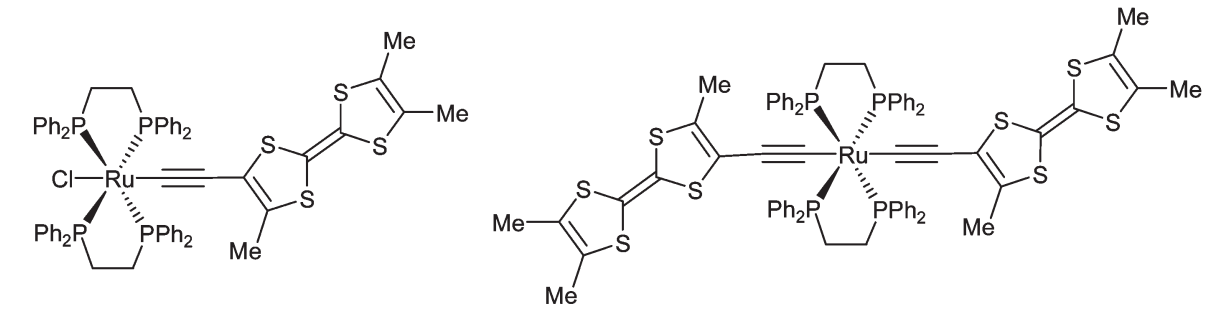

trans-RuCl(C三 $\left.\equiv \mathrm{CMe}_{3} \mathrm{TTF}\right)(\mathrm{dppe})_{2}$

trans-Ru(C $\left.\equiv \mathrm{CMe}_{3} \mathrm{TTF}\right)_{2}(\mathrm{dppe})_{2}$
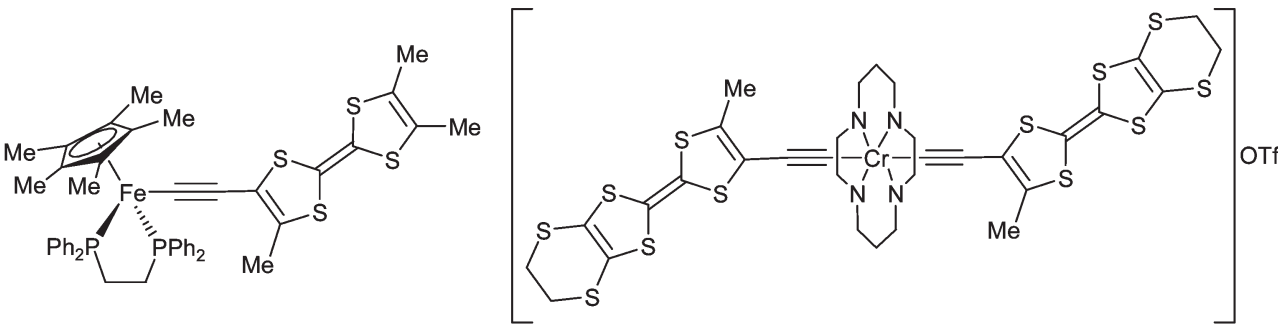

$\mathrm{Cp}^{*}(\mathrm{dppe}) \mathrm{Fe}\left(\mathrm{C} \equiv \mathrm{CMe}_{3} \mathrm{TTF}\right)$

$\left[\right.$ CrCyclam $\left.(\mathrm{C} \equiv \text { CEDTMeTTF })_{2}\right]$ OTf

Chart 1 Metal complexes involving TTF acetylide ligand.

\section{Results and discussion}

\section{Synthesis}

The synthesis of the target complexes is outlined in Scheme 1. The coupling reaction, ${ }^{13}$ catalysed by copper(I) iodide, between 2 equiv. of an alkyne and a bis(chloro)platinum derivative in a basic medium represents a versatile route towards platinum complexes. Accordingly, we prepared four different platinum complexes 1-4 bearing two $\mathrm{Me}_{3}$ TTF-acetylide ligands (Scheme 1). The use of the $\mathrm{Pt}\left(\right.$ bipy) $\mathrm{Cl}_{2}$ precursor affords complex 1 which was found to be insoluble in most of the commonly used organic solvents. To improve the solubility of the target complex, the analogue complex 2 carrying a $t \mathrm{Bu}_{2}$ bipy fragment in place of the bipy fragment in $\mathbf{1}$ was synthesized using $\operatorname{Pt}\left(t \mathrm{Bu}_{2}\right.$ bipy $) \mathrm{Cl}_{2}$ as the starting material. In order to study the influence of the nature of the L-ligand and the cis or trans configuration of the two acetylide TTF moieties around the metal on the physicochemical properties of the platinum complexes, the bipy fragment was replaced by either a diphosphine (1,2-bis(diphenylphosphino)ethane, dppe) ligand or two triphenylphosphine ligands. For that purpose, the cis-Pt(dppe) $\mathrm{Cl}_{2}$ and cis- $\mathrm{Pt}\left(\mathrm{PPh}_{3}\right)_{2} \mathrm{Cl}_{2}$ complexes were used as starting materials for the synthesis of complexes 3 and 4 respectively. The substitution of the chloride ligands on the cis- $\mathrm{Pt}\left(\mathrm{PPh}_{3}\right)_{2} \mathrm{Cl}_{2}$ complex by bulky alkynyl fragments leads to the formation of a more thermodynamically stable transcomplex. ${ }^{14}$ The ${ }^{31} \mathrm{P}$ NMR spectrum of 4 shows one signal at 18 ppm indicating the equivalence of the two phosphorus atoms due to the trans arrangement of the acetylide TTF ligands around the $\mathrm{Pt}(\mathrm{II})$ center.

\section{Molecular structures}

Single crystals were obtained for each complex, 1-4, and the molecular structures have been elucidated by X-ray diffraction studies. Selected bond lengths and angles are reported

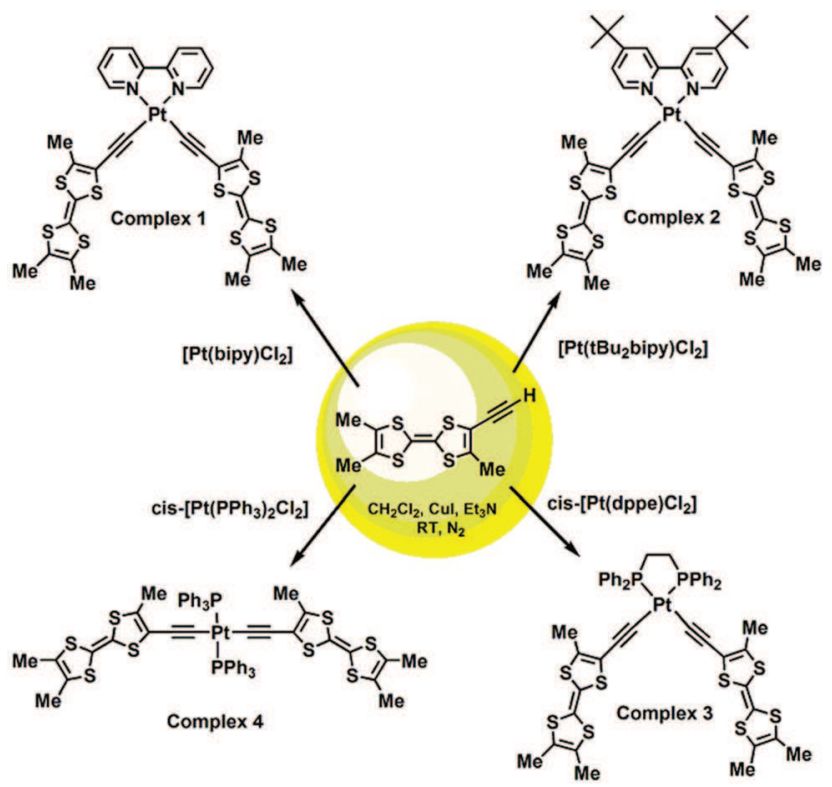

Scheme 1 Synthetic routes for the preparation of complexes 1-4.

in Table 1. All the complexes, $\mathbf{1 - 4}$, display a square planar geometry around the platinum atom. Bond lengths analyses of the central $\mathrm{C}=\mathrm{C}$ bonds reveal that the TTF moieties are all in a neutral state for each complex, 1-4. In complex 1, the two TTF fragments and the bipyridine ligand roughly lie in the same plane and the long axis of the TTF molecules is parallel to the long axis of the bipy fragment (Fig. 1). The observed Pt-N bond lengths as well as the ligand bite angle N1-Pt-N11 (Table 1) compare well with those usually measured in other bipyPt complexes. ${ }^{15}$ The observed Pt-C and $\mathrm{C} \equiv \mathrm{C}$ are identical on the two TTF fragments (Table 1 ). These $\mathrm{C} \equiv \mathrm{C}$ bond lengths are longer than that found in the $\mathrm{Me}_{3} \mathrm{TTFC} \equiv \mathrm{CH}$ precursor $(1.152(8) \AA)^{8}$ but lie in the same range as that found in 
Table 1 Selected bond lengths in $\AA$ and angles in ${ }^{\circ}$

\begin{tabular}{|c|c|c|c|c|c|c|}
\hline Compound & $\mathrm{X}-\mathrm{Pt}$ & Pt-C11 & $\mathrm{C} 10 \equiv \mathrm{C} 11$ & $\mathrm{C} 5=\mathrm{C} 6$ & $\mathrm{X}-\mathrm{Pt}-\mathrm{X}$ & $\mathrm{C}-\mathrm{Pt}-\mathrm{C}$ \\
\hline $\mathrm{Me}_{3} \mathrm{TTFC} \equiv \mathrm{CH}$ & - & - & $1.152(8)$ & $1.349(7)$ & - & - \\
\hline 1 TTFA & N1: $2.068(4)$ & $1.948(8)$ & $1.207(8)$ & $1.353(7)$ & $79.10(15)$ & $88.92(20)$ \\
\hline 2 TTFA & N1: $2.054(5)$ & $1.957(7)$ & $1.184(10)$ & $1.322(9)$ & 78.15(19) & $92.21(24)$ \\
\hline TTFB & N11: $2.062(5)$ & $1.954(6)$ & $1.180(9)$ & $1.322(9)$ & & \\
\hline TTFC & N1: $2.034(7)$ & $1.941(8)$ & $1.215(12)$ & $1.356(11)$ & $80.09(27)$ & $91.02(34)$ \\
\hline TTFD & N11: $2.035(7)$ & $1.952(8)$ & $1.219(12)$ & $1.343(11)$ & & \\
\hline TTFC & P2: $2.283(2)$ & $1.995(6)$ & $1.207(9)$ & $1.343(8)$ & $85.66(7)$ & $88.23(26)$ \\
\hline TTFD & P22: $2.294(2)$ & $2.009(7)$ & $1.186(11)$ & $1.336(9)$ & & \\
\hline $4 \mathrm{TTF}$ & P1: $2.305(1)$ & $1.999(5)$ & $1.220(5)$ & $1.338(6)$ & $180.00(13)$ & $180.00(3)$ \\
\hline
\end{tabular}

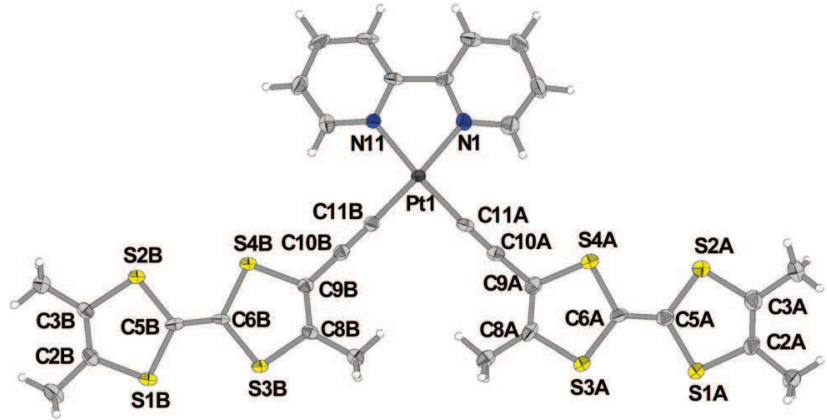

Fig. 1 ORTEP drawing of the platinum complex 1 with the main numbering scheme. Thermal ellipsoids drawn at the $50 \%$ probability level.

trans- $\mathrm{RuCl}\left(-\mathrm{C} \equiv \mathrm{CMe}_{3} \mathrm{TTF}\right)(\mathrm{dppe})_{2} \quad(1.203(3) \quad \AA)^{6}{ }^{6} \quad$ The angle between the two alkynes in $\mathbf{1}$ amounts to 88.92(20) .

The molecular structures of the two crystallographically independent complexes 2 are presented in Fig. 2 and Fig. S1. $\dagger$ In the two complexes, the TTF fragments and the $t \mathrm{Bu}_{2}$ bipy ligand lie in the same plane. Interestingly, the orientation of the TTF molecules observed in the two crystallographically independent molecules of complex 2 is different from that observed in the crystalline structure of the parent complex $\mathbf{1}$. With complex 2, the long axis of the TTF moieties is perpendicular to the long axis of the bipy fragment (Fig. 2). The bond lengths Pt-C, Pt- $\mathrm{N}$ and $\mathrm{C} \equiv \mathrm{C}$ are slightly different in the two crystallographically independent molecules of complex 2 but they remain close to those discussed above for complex $\mathbf{1}$ (Table 1) or to the related Pt(II) diimine acetylide complex. ${ }^{16} \mathrm{~A}$ larger C-Pt-C angle $\left(91.02(34)^{\circ}\right.$ and $\left.92.21(24)^{\circ}\right)$ is observed in the two molecules of complex 2 and can be explained by the peculiar orientation of the TTF moieties in this complex.

The molecular structures of the two crystallographically independent molecules of complexes 3 are presented in Fig. 3 and Fig. S2. $†$ The molecular structure confirms that the platinum center is coordinated by one dppe fragment and two acetylide-TTF ligands in a cis arrangement. The TTF molecules are oriented with the long axis of the TTF parallel to the P...P axis of the dppe fragment. The Pt-C bond lengths are longer in the two molecules of complex 3 than those measured in complexes 1 and 2. This difference is due to a $\pi$-back metal to ligand (bipyridine) donation in complexes 1 and 2 . The Pt-P bond

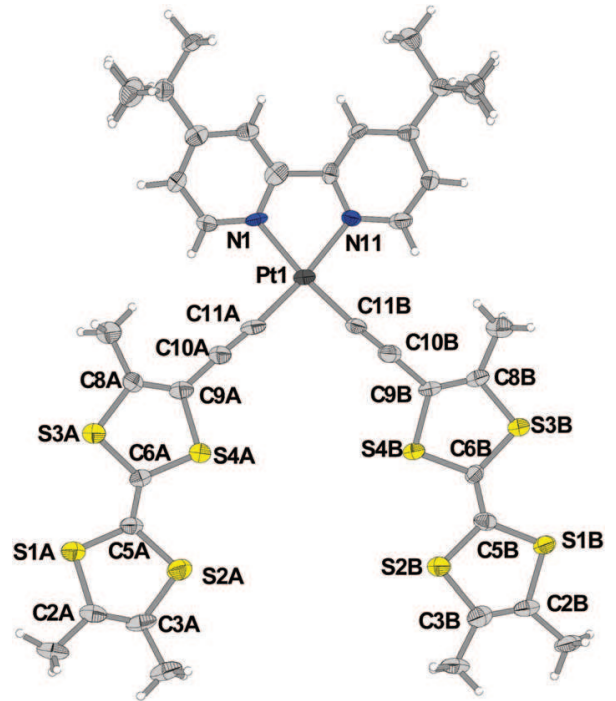

Fig. 2 ORTEP drawing of one of the two crystallographically independent molecules of complex $\mathbf{2}$ with the main numbering scheme. Thermal ellipsoids drawn at the $50 \%$ probability level.

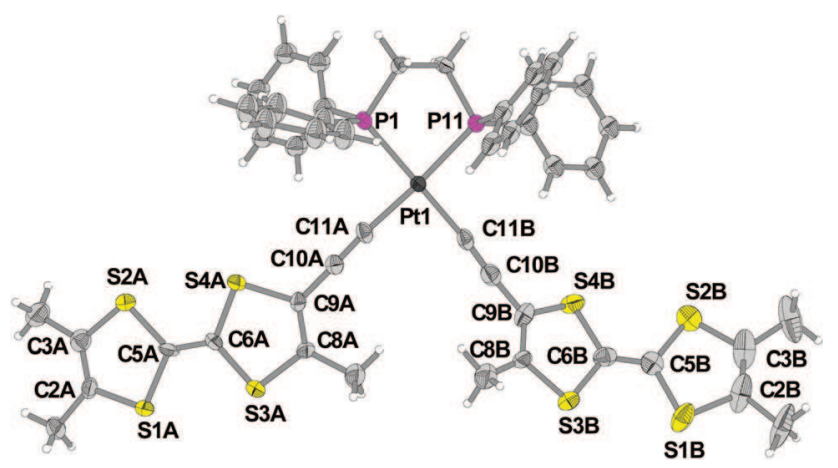

Fig. 3 ORTEP drawing of one of the two crystallographically independent molecules of complex $\mathbf{3}$ with the main numbering scheme. Thermal ellipsoids drawn at the $50 \%$ probability level.

lengths are consistent with those already determined on related phosphino-alkynyl-platinum derivatives. ${ }^{17}$ The $\mathrm{C} \equiv \mathrm{C}$ bond lengths are similar in the two molecules and compare well with those measured in complexes $\mathbf{1}$ and 2 . The TTF cores 


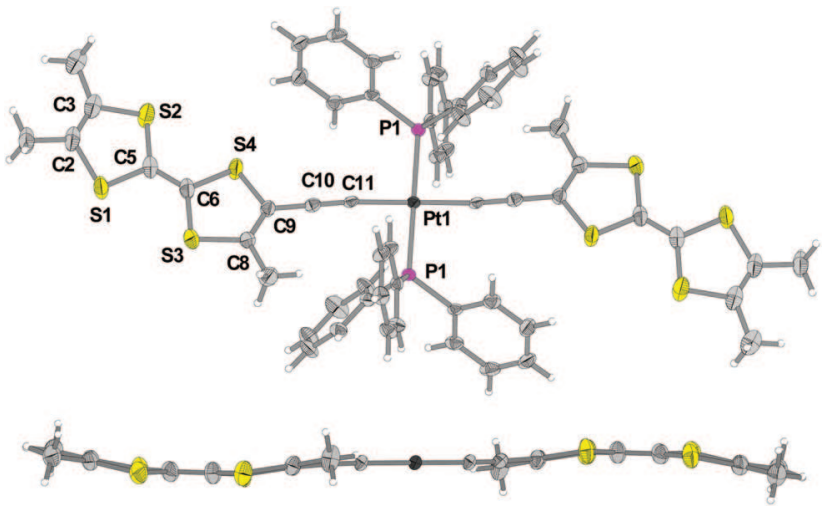

Fig. 4 X-Ray molecular structure of complex 4: ORTEP drawing of the complex (top, thermal ellipsoids drawn at the $50 \%$ probability level), side view of the complex (bottom, the $\mathrm{PPh}_{3}$ ligands have been removed for clarity).

adopt a boat conformation with the dithiole rings folded along the S $\cdots$ S axis $\left(12 / 13^{\circ}\right.$ TTFA, $24 / 14^{\circ}$ TTFB, $13 / 13^{\circ}$ TTFC and $13 /$ $9^{\circ}$ TTFD) contrasting with the planar TTF cores observed for complexes 1 and 2 . On the two crystallographically independent molecules of complex 3 , the two TTF fragments do not lie in the same plane and one TTF clearly appears to be more bent than the other one. This dissymmetry is induced by steric interactions and geometrical constraints imposed by the phenyl rings on the ddpe ligand.

In complex 4, the two acetylide-TTF ligands are in a trans arrangement with the platinum atom localized on the inversion center (Fig. 4). The bond lengths Pt-P, Pt-C, $\mathrm{C} \equiv \mathrm{C}$ compare well with the bond lengths reported for complex 3 and with other similar phosphino-alkynyl-platinum complexes. ${ }^{18}$ The central $\mathrm{C}-\mathrm{C} \equiv \mathrm{C}-\mathrm{Pt}-\mathrm{C} \equiv \mathrm{C}-\mathrm{C}$ spacer is almost linear with angles at $\mathrm{C}-\mathrm{Pt}-\mathrm{C}, \mathrm{Pt}-\mathrm{C} \equiv \mathrm{C}$ and $\mathrm{C} \equiv \mathrm{C}-\mathrm{C}$ of $180.0(0)$, 174.4(3), 177.9(3) ${ }^{\circ}$ respectively. The TTFs adopt a slight boat conformation (Fig. 4).

\section{Photophysical properties of complex 2}

Diimine platinum(II) di(acetylide) complexes are known to display good luminescence properties with bright emission and long decay lifetimes, usually arising predominantly from the ${ }^{3}$ MLCT excited state. ${ }^{19}$ For example, the complex Pt$\left(t \mathrm{Bu}_{2}\right.$ bipy $)(\mathrm{C} \equiv \mathrm{CPh})_{2}$ in $\mathrm{CH}_{2} \mathrm{Cl}_{2}$ emits at $560 \mathrm{~nm}$ with a quantum yield of 0.34 and a luminescence life-time of $1.36 \mu \mathrm{s.} .^{20}$ Acetylide ligands including functional units such as redox-active groups are particularly attractive to obtain redox active optical switches. In this respect, TTF is an efficient luminescent quencher by electron-donating effects and oxidation of the TTF usually leads to the regeneration of the luminescence properties of the luminophore on which this redox unit is attached. ${ }^{21}$ Hence, the luminescence properties of the soluble complex 2 have been explored in the neutral state and upon oxidation of the TTF units by adding successive aliquots of $\mathrm{NOPF}_{6}$ or $\mathrm{FeCl}_{3}$ as the oxidizing agent.

The UV-vis absorption spectrum of complex 2 is shown in Fig. 5 and the absorption maxima and extinction coefficients are given in Table 2. The strong bands below $360 \mathrm{~nm}(\varepsilon \sim 5-6 \times$

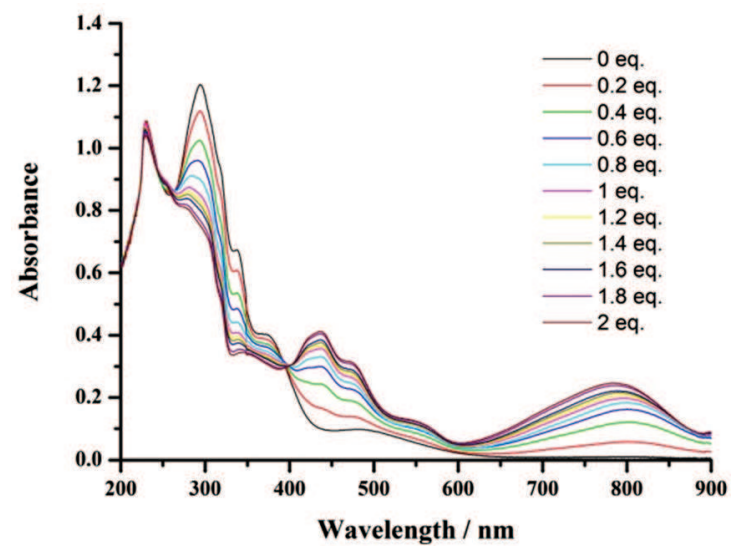

Fig. 5 Evolution of the absorption spectrum of complex 2 in $\mathrm{CH}_{2} \mathrm{Cl}_{2}$ at room temperature upon addition of increasing amounts of $\mathrm{NOPF}_{6}$ as an oxidant.

Table 2 UV-visible and electrochemical data ${ }^{a}$ in V vs. SCE for complexes $\mathbf{2 - 4}$

\begin{tabular}{llll}
\hline Complex & $\lambda_{\max }[\mathrm{nm}]^{b}\left(\varepsilon_{\max }\left[\mathrm{M}^{-1} \mathrm{~cm}^{-1}\right]\right)$ & $E_{1 / 2}{ }^{1} \mathrm{TTF}$ & $E_{1 / 2}{ }^{2} \mathrm{TTF}$ \\
\hline 2 & $229(55000), 294(60000)$, & 0.23 & 0.72 \\
3 & $\begin{array}{l}380(19000), 483(5000) \\
228(52500), 310(41000),\end{array}$ & $0.19 / 0.26$ & 0.75 \\
4 & $405(9000)$ & & \\
$229(68700), 326(41500)$, & 0.21 & 0.72 \\
$\mathrm{Me}_{3}$ TTFC $\equiv \mathrm{CH}$ & $\begin{array}{l}405(11300) \\
295(15000), 331(14000),\end{array}$ & 0.38 & 0.88 \\
& $386(3000)$
\end{tabular}

${ }^{a}$ In $\mathrm{CH}_{2} \mathrm{Cl}_{2}-\left[\mathrm{NBu}_{4}\right]\left[\mathrm{PF}_{6}\right] \quad 0.1 \mathrm{M}$ at room temperature; scan rate, $100 \mathrm{mV} \mathrm{s}^{-1} \cdot E_{1 / 2}=\left(E_{\mathrm{pa}}+E_{\mathrm{pc}}\right) / 2 ; E_{\mathrm{pa}}$ and $E_{\mathrm{pc}}$ are the anodic peak and the cathodic peak potentials, respectively. ${ }^{b}$ Electronic absorption data of complexes 2-4 measured in $\mathrm{CH}_{2} \mathrm{Cl}_{2}$ at room temperature $\left(c \sim 10^{-5} \mathrm{~mol} \mathrm{~L}^{-1}\right)$.

$10^{4} \mathrm{M}^{-1} \mathrm{~cm}^{-1}$ ) are attributed to intraligand ${ }^{1} \pi-\pi^{*}$ transitions localized on the $t \mathrm{Bu}_{2}$ bipy and the alkynyl-TTF fragments. The absorption band observed at $380 \mathrm{~nm}\left(\varepsilon=1.9 \times 10^{4} \mathrm{M}^{-1} \mathrm{~cm}^{-1}\right)$ is attributed to the superimposition of the absorption bands centered on the TTFs and a charge transfer excitation from the $\mathrm{d}$ orbital of the platinum atom to a vacant $\pi^{*}$ diimine orbital (Pt $\rightarrow t \mathrm{Bu}_{2}$ bpy ${ }^{1} \mathrm{MLCT}$ transition). ${ }^{15 a}$ The lowest energy band localized at $483 \mathrm{~nm}\left(\varepsilon=5000 \mathrm{M}^{-1} \mathrm{~cm}^{-1}\right)$ is likely due to a ligand-to-ligand charge transfer transition ( $\left({ }^{1} \mathrm{LL}\right.$ 'CT) between the alkynyl-TTF and the bipy fragments. ${ }^{15 a, 22}$ For complexes 3 and 4 (Fig. S3†), the intense high energy bands below $360 \mathrm{~nm}$ with extinction coefficients $\varepsilon$ of $4-7 \times 10^{5} \mathrm{M}^{-1} \mathrm{~cm}^{-1}$ are assigned to ligand-localized $\pi-\pi^{*}$ transitions whereas the absorption band localized at $405 \mathrm{~nm}$ with a lower extinction coefficient $\left(10^{4} \mathrm{M}^{-1} \mathrm{~cm}^{-1}\right)$ is attributed to a $\pi(\mathrm{C} \equiv \mathrm{C}) \rightarrow \pi^{*}$ $(\mathrm{C} \equiv \mathrm{C})$ transition containing a slight MLCT contribution. ${ }^{23}$ The absorption spectra of the phosphino complexes $\mathbf{3}$ and $\mathbf{4}$ appear to be the superimposition of the absorption spectra of the chloro-phosphino-platinum and of the $\mathrm{Me}_{3} \mathrm{TTF}-\mathrm{C} \equiv \mathrm{C}-\mathrm{H}$ precursors and only a hypsochromic shift of $30 \mathrm{~nm}$ of the low energy band, strongly localized on the acetylide bridge, is observed (Fig. S4†). 

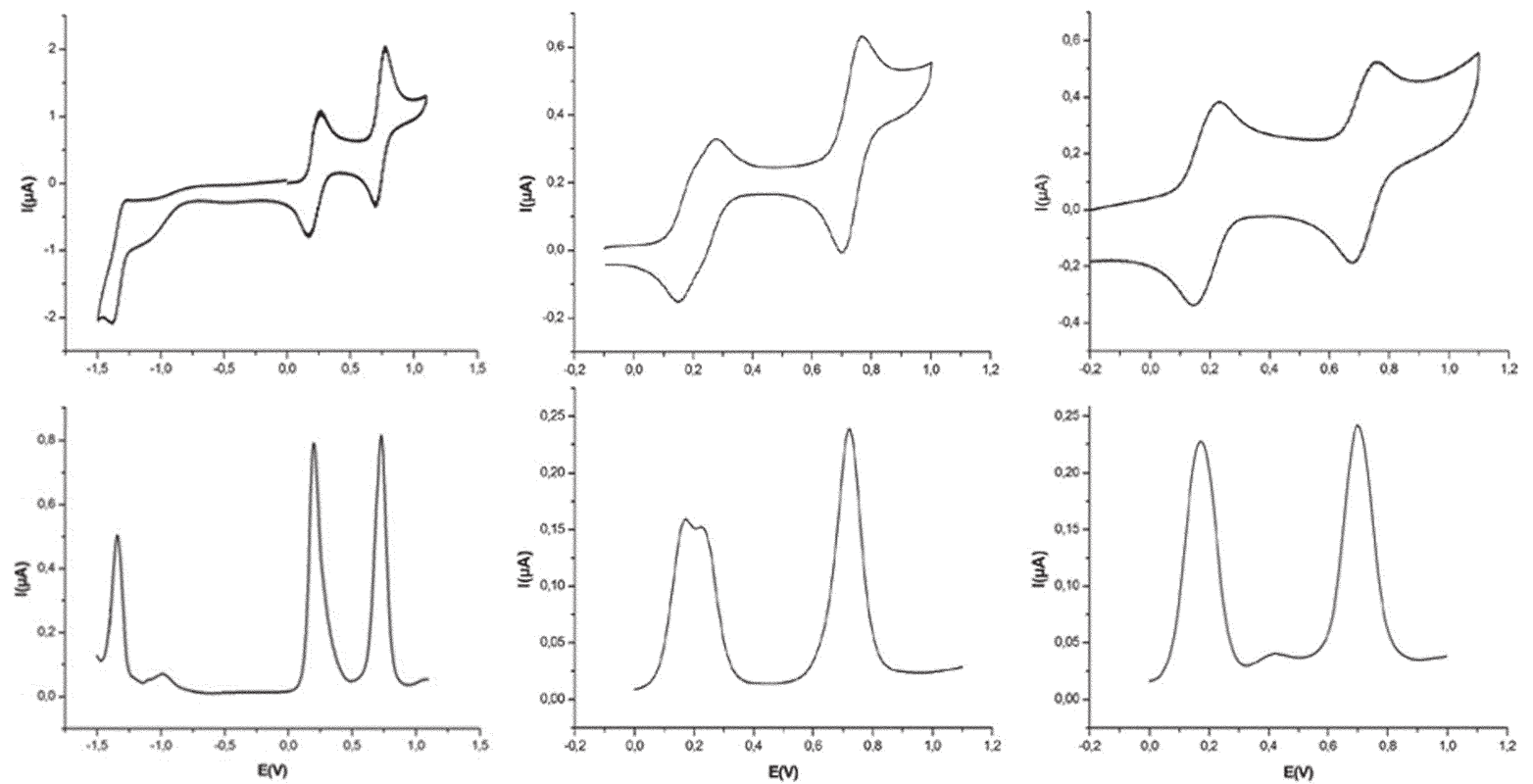

Fig. $6 \mathrm{CV}$ (top) and DPV (bottom) of complexes $\mathbf{2}$ (left), 3 (middle) and 4 (right) in $\mathrm{CH}_{2} \mathrm{Cl}_{2}-\left[\mathrm{NBu}_{4}\right]\left[\mathrm{PF}_{6}\right] 0.1 \mathrm{M}$ (E in $\vee v \mathrm{~s}$. SCE, $v=100 \mathrm{mV} \mathrm{s}{ }^{-1}$ ). The small wave at $-1 \mathrm{~V}$ in $\mathrm{CV}$ of compound $\mathbf{2}$ arises from an unassigned impurity.

At room temperature in $\mathrm{CH}_{2} \mathrm{Cl}_{2}$ (either under air or argon), complex 2 appears to be non-luminescent. Several excitation wavelengths have been tested and excitation in the MLCT band localized at $380 \mathrm{~nm}$ did not lead to the expected emission in the range 570-610 $\mathrm{nm}$, usually observed with diimine platinum(II) di(acetylide) complexes. ${ }^{15 a}$ The luminescence quenching is probably due to photo-induced electron transfer from the TTF unit toward the excited states localized on the platinum-diimine fragments. ${ }^{21}$ Similar electron transfer quenching has already been reported in a related system bearing electron donor phenothiazine instead of TTF. ${ }^{24}$

Chemical oxidation of complex 2 upon addition of increasing amounts of $\mathrm{NOPF}_{6}$ was realized and the evolution of the absorption spectrum is presented in Fig. 5. The gradual oxidation of the TTF units leads to the growing of absorption bands localized at $437 \mathrm{~nm}$ and $800 \mathrm{~nm}$, characteristic of the formation of the cation radical species, and a clear isosbestic point is observed at $400 \mathrm{~nm}$. A decrease of the absorption bands below $330 \mathrm{~nm}$, attributed to $\pi-\pi^{*}$ transitions localized on the neutral TTF units, is also observed. Contrary to our expectations, treatment of the solutions of complex 2 with 1 and 2 equiv. of an oxidizing agent such as $\mathrm{NOPF}_{6}$ or $\mathrm{FeCl}_{3}$ did not lead to the formation of a luminescent complex. This can be ascribed to the fact that the TTF radical cation displays a strong broad absorption band in the wavelength range of 580-800 nm. ${ }^{25}$ Due to spectral overlap between the absorption of the $\mathrm{TTF}^{+}$radical cation and the emission of the diimineplatinum-acetylide core, an energy transfer efficiently takes place. As a consequence, the fluorescence of the diimine-platinum-acetylide core of complex 2 , which would be increased by oxidation of the TTF units, is quenched by energy transfer between the diimine-platinum-acetylide fragment and the $\mathrm{TTF}^{+\cdot}$ radical units. ${ }^{21 e}$

\section{IR studies}

Platinum complexes 1-4 have also been characterized by solidstate IR spectroscopy. The alkynyl $\mathrm{C} \equiv \mathrm{C}$ stretching vibration bands appear at 2090, 2091, 2092 and $2086 \mathrm{~cm}^{-1}$ for complexes 1 to 4 respectively. These values are almost identical in the four complexes and this indicates that there is little effect of either the L-ligand (bipy for 1 and 2, dppe for 3 and $\mathrm{PPh}_{3}$ for 4 ) or the cis/trans geometry on the frequency of the $\nu_{\mathrm{C}} \equiv \mathrm{C}$ stretching vibration.

\section{Electrochemical studies}

The electrochemical properties of complexes 2-4 were investigated by cyclic voltammetry in $\mathrm{CH}_{2} \mathrm{Cl}_{2}$ using $\left[\mathrm{NBu}_{4}\right]\left[\mathrm{PF}_{6}\right]$ as a supporting electrolyte. Due to its insolubility, the redox properties of complex 1 could not be determined. The cyclic voltammograms (CV) of complexes 2-4 are presented in Fig. 6 and the electrochemical data are collected in Table 2. Complexes 2, 3 and $\mathbf{4}$ display two main reversible oxidation waves. Complex 2 displays an additional reduction wave at $E_{\text {red }}=-1.32 \mathrm{~V} v s$. SCE attributed to the one-electron reduction of the $t \mathrm{Bu}_{2}$ bipy fragment. $^{20} \mathrm{~A}$ closer look at the $\mathrm{CV}$ pattern of complex 3 reveals that the first redox system originates from two closely spaced and resolved oxidation processes at $E_{1 / 2}=0.19 \mathrm{~V}$ and $E_{1 / 2}=0.26 \mathrm{~V} v s$. SCE, respectively corresponding to the successive generation of the TTF cation radical and the bis(TTF cation radical). The corresponding first oxidation systems in 2 and $\mathbf{4}$ are not resolved. However, they also involve two closely spaced one-electron transfers assigned to the oxidation of the TTF cores into the corresponding bis(TTF cation radical) $2^{2(+\cdot)}$ and $4^{2(+\cdot)}$. For all 2, 3 and 4 , the second oxidation process is assigned to the closely spaced and unresolved second oxidation of the bis(TTF cation radical) $2^{2(+\cdot)}, 3^{2(+\cdot)}$ and $4^{2(+\cdot)}$ 
into the bis(TTF dication) $2^{4+}, 3^{4+}$ and $4^{4+}$. Note that none of these two-electron transfers involve inversion of the normal potential ordering. Rather, they all involve sequential and closely spaced one-electron transfer. Only the first oxidation system of 3 may be resolved electrochemically. The oxidation potentials of the TTF moieties are comparable in the three complexes indicating that the nature of the coordinating L-ligand (bipyridine or phosphine) has no significant influence on the electron-donating ability of the TTF core. Compared with the oxidation potentials of the $\mathrm{Me}_{3} \mathrm{TTFC} \equiv \mathrm{CH}$ precursor $\left(E_{1 / 2}{ }^{1}=0.38 \mathrm{~V}\right.$ and $E_{1 / 2}{ }^{2}=0.88 \mathrm{~V} v s$. SCE, in $\left.\mathrm{CH}_{2} \mathrm{Cl}_{2}\right)$, all the oxidation potentials of the TTF cores within all these complexes, 2-4 (Table 2), are shifted by $160 \mathrm{mV}$ towards less anodic potentials. This cathodic shift reveals that the organometallic fragment, through the acetylide linker, increases the electron density on the TTF cores and thus highlights the electronic interaction between the platinum center and the TTF cores. Such a cathodic shift has only been previously observed in a few cases such as for $\left(\mathrm{Me}_{2} \mathrm{TTF}\left(\mathrm{SiMe}_{2}\right)_{2}\right) \mathrm{Pt}\left(\mathrm{PPh}_{3}\right)_{2},{ }^{26}$ trans$\mathrm{ClRu}\left(\mathrm{C} \equiv \mathrm{CMe}_{3} \mathrm{TTF}\right)(\mathrm{dppe})_{2}{ }^{6}$ and trans-Ru(C $\left.\equiv \mathrm{CMe}_{3} \mathrm{TTF}\right)_{2^{-}}$ (dppe $)_{2}{ }^{8}$ It is worth noting that this shift depends on the metal linked to the TTF acetylide ligand. Indeed, in the case of the chromium or iron acetylide-TTF type complex, namely $\left[\right.$ CrCyclam $\left(\mathrm{C} \equiv \mathrm{CEDTMeTTF}_{2}\right] \mathrm{OTf}^{9} \quad$ and $\quad \mathrm{Cp}^{*}(\mathrm{dppe}) \mathrm{FeC} \equiv$ $\mathrm{C}-\mathrm{TTFMe}_{3},{ }^{7}$ no modification of the oxidation potentials of the TTF was observed. In other cases, when interactions exist between a TTF core connected to a metallic center through coordinating heteroatoms (L-type TTF ligands), an anodic shift is usually observed. ${ }^{1}$

The splitting of the first oxidation process of $\mathbf{3}$ was confirmed by differential pulse voltammetry (DPV) analysis performed on the three complexes 2-4 (Fig. 6). The DPV of complex 3 displays two main oxidation peaks and clearly the first oxidation system contains two contributions at 0.19 and $0.26 \mathrm{~V}$, corresponding to two monoelectronic oxidation processes. Hence, each TTF unit in $\mathbf{3}$ is oxidized to the cation radical sequentially, with a potential difference of $\Delta E=70 \mathrm{mV}$, whereas the last oxidation process at $0.75 \mathrm{~V}$ is unresolved and involves two electrons. The DPV of complex 2 confirms the presence of three redox processes and integration of the waves confirms that the reduction process contains one electron whereas each oxidation peak is unresolved and involves two electrons. Similarly for complex 4, only two unresolved twoelectron oxidation peaks are effectively observed in the anodic region.

The splitting of the first oxidation process for 3 is independent of the concentration $\left(10^{-4}\right.$ to $\left.10^{-6} \mathrm{M}\right)$, indicating that the sequential oxidation of the TTF cores is due to intramolecular interactions. This behavior is reminiscent of what was previously observed with dimeric TTFs where the splitting of the first redox process was the result of intramolecular interactions either through space, due to spatial proximity of the TTF cores, or through bond, due to electronic coupling of the TTF cores along the linker. ${ }^{27}$ For related platinum complexes containing two organometallic electrophores such as ferrocene instead of the TTF cores, the trans-Pt $\left(\mathrm{PPh}_{2} \mathrm{Me}\right)_{2}(\mathrm{C} \equiv \mathrm{CFc})_{2}$ and the
cis-Pt(dppe) $(\mathrm{C} \equiv \mathrm{CFc})_{2}$, both ferrocene moieties are oxidized successively with a potential difference $(\Delta E)$ of 80 and $70 \mathrm{mV}$, respectively. ${ }^{11}$ The splitting value of $70 \mathrm{mV}$ measured with complex 3 is in the same range and can indicate that weak intramolecular interactions occur between the two electrophores. However, a question remains, why this splitting is observed for the cis isomer $\mathbf{3}$ and not for the trans isomer $\mathbf{4}$ as in the case of the ferrocene complexes.

Regarding spatial interactions, it has been demonstrated that in TTF dimers linked by one heteroatom, the extent of the spatial intramolecular interactions increases when the angle between the two TTF moieties decreases. ${ }^{28}$ The $\mathrm{C}-\mathrm{Pt}-\mathrm{C}$ angle determined in the crystalline structure of complex 3 appears smaller than that measured on the crystalline structure of complex 2. This smaller angle between the two TTF units in complex 3 can be at the origin of the splitting of the oxidation waves by increasing the spatial interactions (not observed with complex 2). However, measurements in the poorly coordinating electrolyte, ${ }^{29} \mathrm{CH}_{2} \mathrm{Cl}_{2}-\mathrm{Na}\left[\mathrm{B}\left(\mathrm{C}_{6} \mathrm{H}_{4}\left(\mathrm{CF}_{3}\right)_{2}\right)_{4}\right] 0.02 \mathrm{M}$, do not yield a better resolution of the first two electron wave for any of the three complexes 2-4, showing that the TTF cores poorly interact electrostatically.

\section{UV-vis-NIR spectroelectrochemical investigations}

In order to get more insight into the interplay between the electroactive TTF through the bisacetylide-Pt bridge, UV-visNIR spectroelectrochemical investigations were carried out on complexes 2, 3 and 4 in a $\mathrm{CH}_{2} \mathrm{Cl}_{2}-\left[\mathrm{NBu}_{4}\right]\left[\mathrm{PF}_{6}\right] 0.2 \mathrm{M}$ solution (Fig. 7). The gradual oxidation of the TTF cores only induces the growth of low energy bands characteristic of radical cation species at $400 \mathrm{~nm}$ and $800 \mathrm{~nm}$. No evidence of intervalence charge-transfer (IVCT) bands was observed for complexes 2-4 in the measured range from 200-2000 nm (5000-50000 $\mathrm{cm}^{-1}$ ) (Fig. 7). Although we cannot exclude the presence of an IVCT band at lower energy, these results suggest a lack of strong electronic communication between the TTF moieties in the mono-oxidized complexes in all three complexes (2-4). In a related trans-ruthenium complex, ${ }^{8}$ a corresponding potential splitting of $110 \mathrm{mV}$ was measured electrochemically and a band assigned as an IVCT recorded at $1360 \mathrm{~nm}$.

\section{DFT computational studies}

DFT calculations [Gaussian03, B3LYP/LanL2DZ] were performed on complexes 2, 3 and 4. Full geometry optimization led to the molecular structure represented in Fig. 8 and 9. The optimized geometries are in good agreement with those obtained by X-ray diffraction studies concerning the bond lengths and the bond angles (vide supra). As shown in Fig. 8, the HOMOs (highest occupied molecular orbitals) of complexes $\mathbf{2}$ and $\mathbf{4}$ are symmetric and have a strong TTF character with a poor contribution of the bisacetylide-Pt spacer and also with poor coefficients found on the carbon atoms of the distal dithiole rings. The introduction of the bisacetylide organometallic fragment between the two TTF moieties induces a dissymmetrization of the HOMO on the TTF core as the HOMO of the neutral $\mathrm{Me}_{3} \mathrm{TTF}-\mathrm{C} \equiv \mathrm{C}-\mathrm{H}$ precursor is symmetric on the 


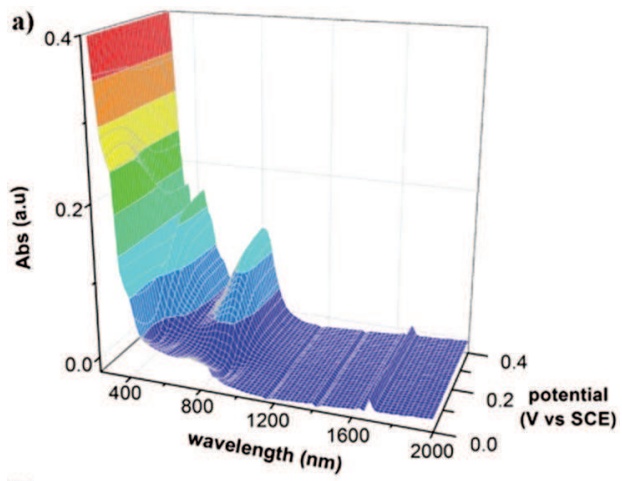

b)
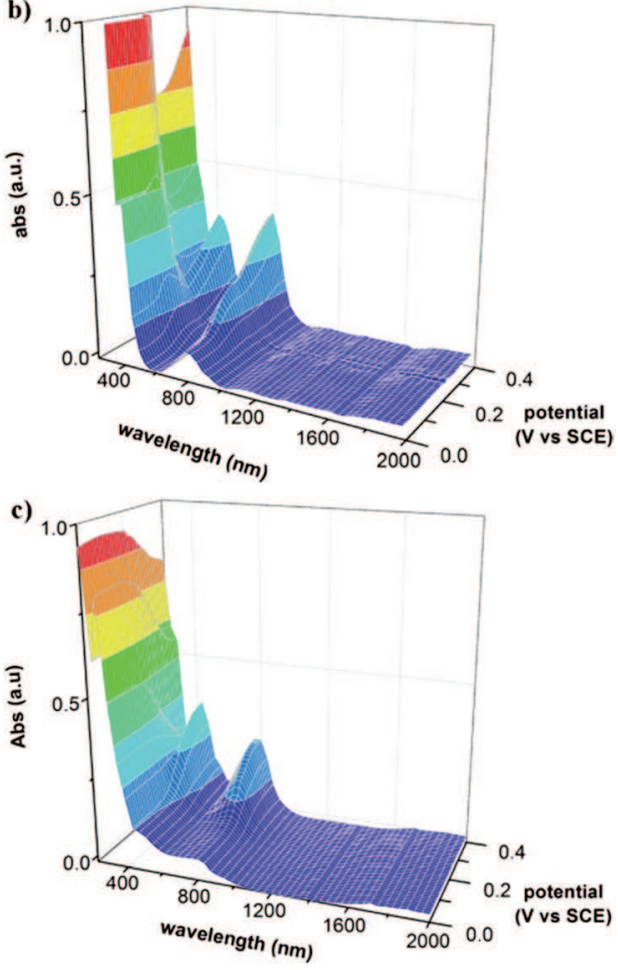

Fig. 7 UV-vis-NIR monitoring of the electrochemical oxidation of cis- $\mathrm{Pt}\left(t \mathrm{Bu} \mathrm{u}_{2}\right.$ bipy) $\left(\mathrm{C} \equiv \mathrm{CMe}_{3} \mathrm{TTF}\right)_{2} \mathbf{2}$ (a), cis-Pt(dppe)( $\left(\mathrm{CCMe}_{3} \mathrm{TTF}\right)_{2} \mathbf{3}$ (b) and trans$\mathrm{Pt}\left(\mathrm{PPh}_{3}\right)_{2}\left(\mathrm{C} \equiv \mathrm{CMe}_{3} \mathrm{TTF}\right)_{2} 4$ (c) from $0 \mathrm{~V}$ to $0.4 \mathrm{~V}$ in $\mathrm{CH}_{2} \mathrm{Cl}_{2}-\left[\mathrm{NBu}_{4}\right][\mathrm{PF} 6] 0.2 \mathrm{M}$.

TTF core with no contribution from the alkyne. ${ }^{6,8}$ The SOMOs (highest singly occupied molecular orbitals) of the oxidized complexes $2^{+\cdot}$ and $4^{+}$are essentially localized on the TTF cores with no contribution from the platinum center. The calculated spin densities of complexes $2^{+\cdot}$ and $4^{+\cdot}$ appear to be delocalized over the whole molecule with however weaker contribution of the organometallic bridge. The poor delocalization through the acetylide-platinum-acetylide organometallic linker in the cation radical is consistent with the unresolved first oxidation measured electrochemically (low $\Delta E$ ). Results obtained with complexes 2 and $\mathbf{4}$ are quite similar regardless of the cis or trans arrangement with even poorer contribution of the organometallic linker in the spin density of $2^{+}$.

DFT calculations performed on complex 3 reveal that the HOMO is dissymmetric with the electronic density localized on one of the two TTF cores (Fig. 9). Such dissymmetry is consistent with the crystal structure of complex 3 (vide supra). It is worth mentioning that such dissymmetry has not been evidenced on the ${ }^{1} \mathrm{H}$ NMR and ${ }^{31} \mathrm{P}$ NMR spectra. The HOMO is centered on one TTF unit and the HOMO - 1 is localized on the other TTF unit with energy levels calculated at -4.33 and $-4.41 \mathrm{eV}$ respectively. The dissymmetry is attributed to steric hindrance due to the bulky dppe ligand and the close proximity of the phenyl groups which force the TTF units to be in two distinct environments. With the rigid and symmetric $t \mathrm{Bu}_{2}$ bipy fragment in complex 2 , the two TTF fragments have the same environment and are equivalent, leading to a closely spaced and unresolved first oxidation potential. In complex $\mathbf{4}$, the TTF cores are also equivalent and the conformation of the TTF cores is not constrained by the presence of $\mathrm{PPh}_{3}$ groups. Interestingly, the SOMO of complex $3^{+\cdot}$ is perfectly symmetric with a main contribution of two equivalent TTF cores. The spin density in the mono-oxidized species $3^{+\cdot}$ is essentially localized on the TTF fragments with a slight delocalization on the organometallic bridge.

Contrary to complexes 2 and $\mathbf{4}$, complex $\mathbf{3}$ presents two resolved sequential oxidations. This peculiar electrochemical behavior is likely due to geometrical constraints and interactions with the phenyl groups of the structurally blocked and distorted dppe ligand. For all complexes, the lack of effect of the poorly coordinating electrolyte ${ }^{29}$ on the splitting of the first wave and the lack of spectroscopic evidence for intervalence charge transfer excludes a strong interaction between the two TTF moieties and lends more support to the proposed explanation based on the demonstrated structural non-equivalence of the two organic electrophores.

\section{Conclusions}

In summary, we have presented a series of cis and trans platinum complexes bearing two TTF-ligands. Four complexes, cis-Pt(bipy)(C三 $\left.\equiv \mathrm{CMe}_{3} \mathrm{TTF}\right)_{2}$ (1), cis-Pt $\left(t \mathrm{Bu}_{2}\right.$ bipy $)\left(\mathrm{C} \equiv \mathrm{CMe}_{3} \mathrm{TTF}\right)_{2}$ (2), cis-Pt(dppe) $\left(\mathrm{C} \equiv \mathrm{CMe}_{3} \mathrm{TTF}\right)_{2} \quad$ (3) and trans- $\mathrm{Pt}\left(\mathrm{PPh}_{3}\right)_{2}$ $\left(\mathrm{C} \equiv \mathrm{CMe}_{3} \mathrm{TTF}\right)_{2}(4)$, were readily synthesized and characterized in order to study the influence of the nature of the L-ligands and the cis/trans geometry of the acetylide ligands on the electronic properties of the complexes. The luminescence of the bipy-platinum-alkynyl fragment is quenched in the neutral state by intramolecular photoinduced electron transfer from TTF donors. However, chemical oxidation of the TTF moieties by $\mathrm{NOPF}_{6}$ or $\mathrm{FeCl}_{3}$ did not restore the luminescence properties of the diimine-platinum-acetylide complex. The luminescence of the oxidized complex is most likely quenched by energy transfer toward the formed $\mathrm{TTF}^{+}$' radical cation. Electrochemical measurements and DFT calculations have revealed that in complexes 2 and 4, the two TTF units on each complex are equivalent and are oxidized to the radical cation at closely spaced and unresolved potentials. No evidence of electronic communications between the two TTF units through the organometallic fragment was found in these complexes, especially no intervalence charge-transfer (IVCT) bands are 


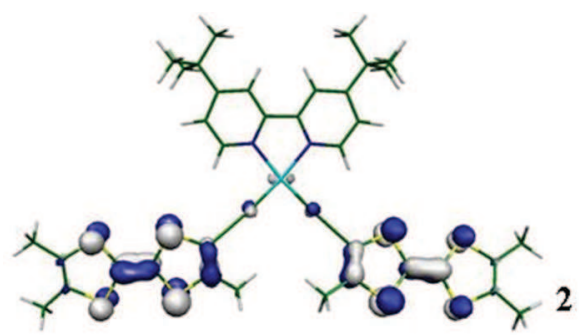

HOMO
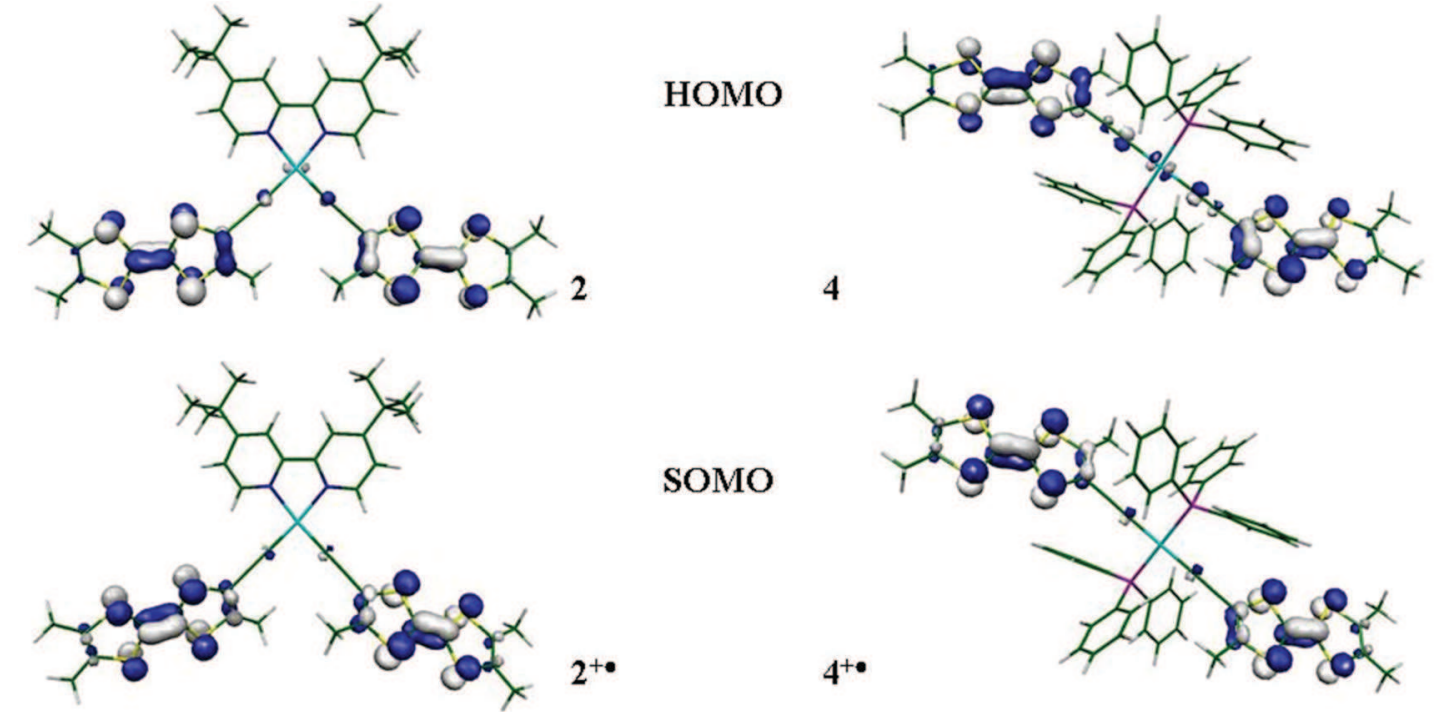

SOMO

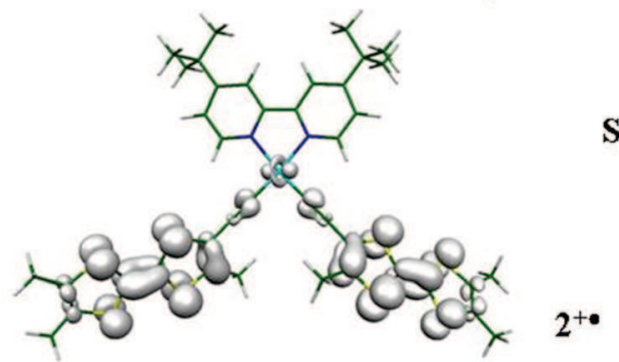

Spin Density

$4^{+\bullet}$

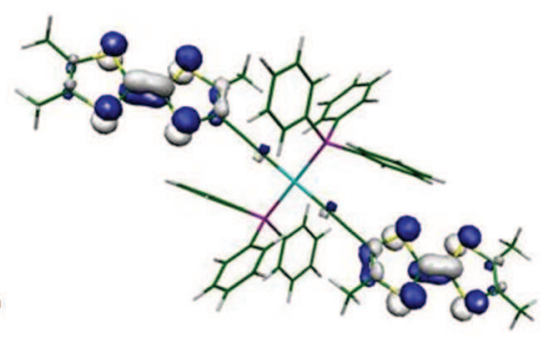

$4^{+\bullet}$

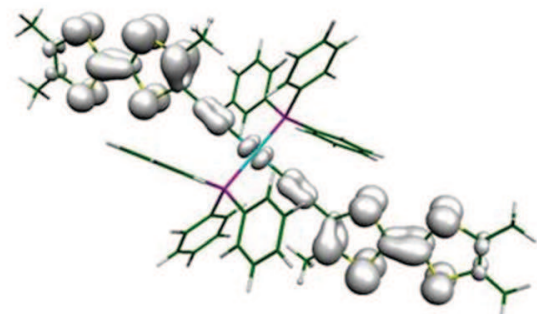

Fig. 8 Graphical representations of the HOMO and SOMO of complexes 2 and $\mathbf{4}^{30}$ shown with a cut-off of 0.04 [e bohr $\left.{ }^{-3}\right]^{1 / 2}$ and spin density of the monooxidized complexes $\mathbf{2}^{\mathbf{+}^{*}}$ and $\mathbf{4}^{+\cdot}$ shown with a cut-off of $0.001 \mathrm{e} \mathrm{bohr}{ }^{-3}$.

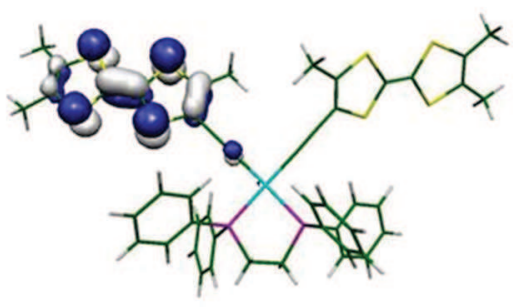

HOMO

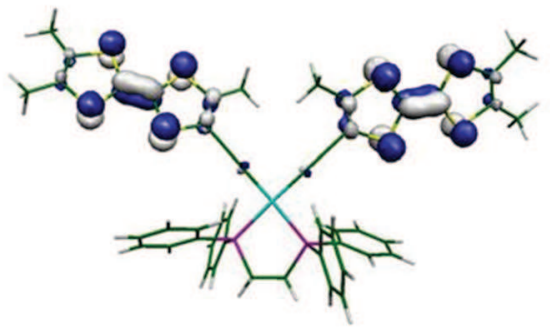

SOMO

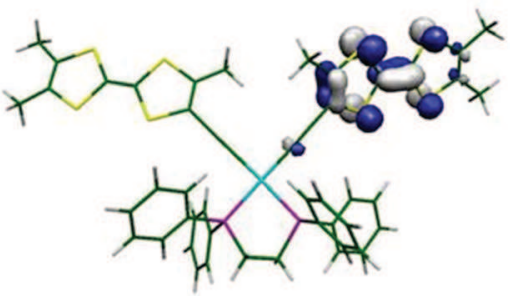

HOMO-1

$3^{+\bullet}$

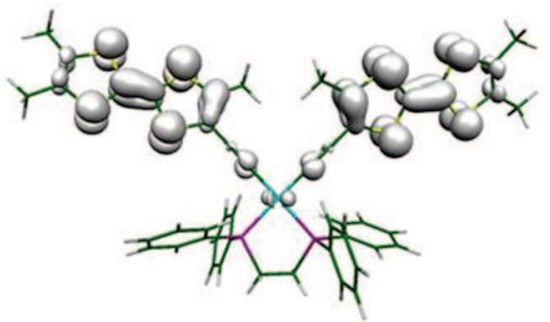

Spin Density

Fig. 9 Graphical representations of the HOMO and SOMO of complexes 3 and $\mathbf{3}^{+\cdot}$ shown with a cut-off of 0.04 [e bohr $\left.{ }^{-3}\right]^{1 / 2}$ and spin density of the monooxidized complexes $\mathbf{3}^{+*}$ shown with a cut-off of 0.001 e bohr ${ }^{-3}$. 
observed during the spectroelectrochemical studies. Based on these preliminary measurements, we conclude that alkynylplatinum fragments do not allow efficient electronic communications between the two organic electrophores in contrast to alkynyl-ruthenium fragments. DFT calculations show a dissymmetry of the two TTF ligands in complex 3 also observed in the crystal structure. This is proposed to account for the more pronounced splitting of the first oxidation wave, as strong electronic coupling was ruled out by spectroelectrochemical investigations.

\section{Experimental section}

General

NMR spectra were recorded on a Bruker AV300III spectrometer at room temperature using perdeuterated solvents. Chemical shifts are reported in $\mathrm{ppm}$ referenced to TMS for ${ }^{1} \mathrm{H} \mathrm{NMR}$, ${ }^{13} \mathrm{C}$ NMR and to $\mathrm{H}_{3} \mathrm{PO}_{4}$ for ${ }^{31} \mathrm{P}$ NMR. FT-IR spectra were recorded using a Varian-640 FT-IR spectrometer equipped with a PIKE ATR apparatus. Fluorescence spectra were recorded on a Fluorolog-3 fluorescence spectrometer (FL3-22, Horiba Jobin Yvon) with $1 \mathrm{~cm}$ quartz cells. Mass spectra were recorded with a Bruker MicrOTOF-Q II instrument for complexes 1, 3 and 4 and with a Micromass ZABSpecoaTOF instrument for complex 2 by the Centre Régional de Mesures Physiques de l'Ouest, Rennes. CVs were carried out on a $10^{-3} \mathrm{M}$ solution of the complex in $\mathrm{CH}_{2} \mathrm{Cl}_{2}-\left[\mathrm{NBu}_{4}\right]\left[\mathrm{PF}_{6}\right] 0.1 \mathrm{M}$ and in $\mathrm{CH}_{2} \mathrm{Cl}_{2}-\mathrm{Na}$ $\left[\mathrm{B}\left(\mathrm{C}_{6} \mathrm{H}_{4}\left(\mathrm{CF}_{3}\right)_{2}\right)_{4}\right] 0.02 \mathrm{M}$. Sodium tetrakis[3,5-bis(trifluoromethyl)phenyl]borate, $\mathrm{Na}\left[\mathrm{B}\left(\mathrm{C}_{6} \mathrm{H}_{4}\left(\mathrm{CF}_{3}\right)_{2}\right)_{4}\right]$, was purchased from Aldrich. Spectroelectrochemical experiments were carried out in a $1 \mathrm{~mm}$ length quartz cell. The electrochemical set-up was constituted by a micro-perforated platinum-iridium foil as a working electrode, a platinum wire as a counter electrode and an SCE as a reference electrode. A Model 362 scanning potentiostat from EG\&G Instruments was used to set the applied potential and a Cary 5 spectrophotometer was employed to record the UV-vis-NIR spectra. All experiments were performed in $\mathrm{CH}_{2} \mathrm{Cl}_{2}-\left[\mathrm{NBu}_{4}\right]\left[\mathrm{PF}_{6}\right] 0.2 \mathrm{M}$. CVs were recorded on a Model 362 scanning potentiostat from EG\&G Instruments at $0.1 \mathrm{~V} \mathrm{~s}^{-1}$ on a platinum disk electrode $\left(1 \mathrm{~mm}^{2}\right)$. Potentials were measured versus a $\mathrm{KCl}$ saturated calomel electrode (SCE). Anhydrous $\mathrm{CH}_{2} \mathrm{Cl}_{2}$ and $\mathrm{NEt}_{3}$ were obtained by distillation over $\mathrm{P}_{2} \mathrm{O}_{5}$ and $\mathrm{CaH}_{2}$ respectively. All synthetic manipulations were performed under an inert and dry nitrogen atmosphere using standard Schlenk techniques. Silica gel used in chromatographic separations was obtained from Acros Organics (Silica Gel, ultra pure, 40-60 $\mu \mathrm{m})$. The ethynyltrimethyl-TTF ( $\left.\mathrm{HC} \equiv \mathrm{CMe}_{3} \mathrm{TTF}\right)$ was prepared according to a previously published procedure. ${ }^{6,8}$ cis- $\mathrm{Pt}\left(\mathrm{PPh}_{3}\right)_{2} \mathrm{Cl}_{2}$ was prepared by the Jensen method. ${ }^{31}$ The complex cis-Pt(dppe) $\mathrm{Cl}_{2}$ was prepared by following the literature methods. ${ }^{32}$ All other reagents and materials from commercial sources were used without further purification.

Complex 1 cis-Pt(bipy)(C $\left.\equiv \mathrm{CMe}_{3} \mathbf{T T F}\right)_{2}$. Pt(bipy)Cl $\mathrm{Cl}_{2}$ (47 mg, $0.11 \mathrm{mmol})$ was reacted with $\mathrm{HC} \equiv \mathrm{CMe}_{3} \mathrm{TTF}(60 \mathrm{mg}$,
$0.22 \mathrm{mmol})$ in distilled $\mathrm{CH}_{2} \mathrm{Cl}_{2}(10 \mathrm{~mL})$ in the presence of freshly-distilled $\mathrm{NEt}_{3}(5 \mathrm{~mL})$ and $\mathrm{CuI}(4 \mathrm{mg}, 0.022 \mathrm{mmol})$ as a catalyst. The reaction mixture was stirred under an inert nitrogen atmosphere at room temperature for $24 \mathrm{~h}$. A black precipitate was filtered off and washed with methanol and $\mathrm{CH}_{2} \mathrm{Cl}_{2}$. After drying, $65 \mathrm{mg}$ of black powder were isolated (yield = $65 \%$ ). Single crystals were harvested by slow cooling of a clear hot DMF solution of $\mathbf{1}$. Due to its low solubility complex 1 could not be characterized by ${ }^{13} \mathrm{C}$ NMR. ${ }^{1} \mathrm{H}$ NMR (hot $\mathrm{D}_{6}$-DMSO) $\delta(\mathrm{ppm}) 1.94\left(\mathrm{~s}, 12 \mathrm{H}, \mathrm{CH}_{3}\right), 2.26\left(\mathrm{~S}, 6 \mathrm{H}, \mathrm{CH}_{3}\right), 7.91$ (m, 2H, CH), $8.42(\mathrm{~m}, 2 \mathrm{H}, \mathrm{CH}), 8.67(\mathrm{~m}, 2 \mathrm{H}, \mathrm{CH}), 9.30(\mathrm{~m}, 2 \mathrm{H}$, $\mathrm{CH})$ ). IR (ATR): $2090 \mathrm{~cm}^{-1}\left(\nu_{\mathrm{C} \equiv \mathrm{C}}\right)$; HRMS (ESI): $\mathrm{m} / \mathrm{z}$ calcd for $\mathrm{C}_{32} \mathrm{H}_{26} \mathrm{~N}_{2} \mathrm{~S}_{8}{ }^{194} \mathrm{Pt}$ : 887.9483. Found: 887.9483.

Complex 2 cis-Pt $\left(\boldsymbol{t B u _ { 2 }}\right.$ bipy $)\left(\mathrm{C} \equiv \mathbf{C M e}_{3} \mathbf{T T F}\right)_{2} \cdot \operatorname{Pt}\left(t \mathrm{Bu}_{2}\right.$ bipy $) \mathrm{Cl}_{2}$ (99 mg, $0.185 \mathrm{mmol}$ ) and $\mathrm{HC} \equiv \mathrm{CMe}_{3} \mathrm{TTF}$ (100 mg, $0.37 \mathrm{mmol}$ ) were dissolved in distilled $\mathrm{CH}_{2} \mathrm{Cl}_{2}(10 \mathrm{~mL})$ in a Schlenk tube. Nitrogen was bubbled through the mixture for $30 \mathrm{~min}$, after which CuI (7 mg, $0.037 \mathrm{mmol}$ ) and freshly-distilled $\mathrm{NEt}_{3}$ $(5 \mathrm{~mL})$ were added and the mixture stirred at room temperature for $24 \mathrm{~h}$. The solvent was rotary evaporated and the residue treated with water and extracted with $\mathrm{CH}_{2} \mathrm{Cl}_{2}$. The organic layer was washed with water and dried over $\mathrm{MgSO}_{4}$. The residue was purified by column chromatography on silica gel with $\mathrm{CH}_{2} \mathrm{Cl}_{2}$ as the eluent. The product was isolated as a red powder in $61 \%$ yield $(0.10 \mathrm{~g})$. Single crystals were obtained by slow evaporation of a concentrated $\mathrm{CH}_{2} \mathrm{Cl}_{2}$ solution of $2 .{ }^{1} \mathrm{H}$ NMR $\left(\mathrm{CDCl}_{3}\right) \delta 1.47\left(\mathrm{~s}, 18 \mathrm{H}, \mathrm{CH}_{3}\right), 1.95\left(\mathrm{~s}, 12 \mathrm{H}, \mathrm{CH}_{3}\right), 2.21(\mathrm{~s}$, $\left.6 \mathrm{H}, \mathrm{CH}_{3}\right), 7.54(\mathrm{~m}, 2 \mathrm{H}, \mathrm{CH}), 7.99(\mathrm{~m}, 2 \mathrm{H}, \mathrm{CH}), 9.34(\mathrm{~m}, 2 \mathrm{H}$, $\mathrm{CH}) ;{ }^{13} \mathrm{C} \mathrm{NMR}\left(\mathrm{CDCl}_{3}\right) \delta 12.7,29.2,34.8,93.7,118.1,121.5$, 121.7, 123.6, 149.7, 155.1, 162.5; IR (ATR): $2091 \mathrm{~cm}^{-1}\left(\nu_{\mathrm{C} \equiv \mathrm{C}}\right)$; HRMS (LSIMS): $m / z$ calcd for $\mathrm{C}_{40} \mathrm{H}_{42} \mathrm{~N}_{2} \mathrm{~S}_{8}{ }^{194} \mathrm{Pt}$ : 1000.0740 . Found: 1007.0740 .

Complex 3 cis-Pt(dppe)(C $\left.\equiv \mathbf{C M e}_{3} \mathbf{T T F}\right)_{2} \cdot$ cis-Pt(dppe) $\mathrm{Cl}_{2}$ (100 $\mathrm{mg}, 0.15 \mathrm{mmol}$ ) was introduced in a Schlenk tube with $\mathrm{HC} \equiv \mathrm{CMe}_{3} \mathrm{TTF}$ (81 mg, $0.30 \mathrm{mmol}$ ) in distilled $\mathrm{CH}_{2} \mathrm{Cl}_{2}(10 \mathrm{~mL})$ in the presence of freshly-distilled $\mathrm{NEt}_{3}(5 \mathrm{~mL})$ and $\mathrm{CuI}(6 \mathrm{mg}$, $0.030 \mathrm{mmol}$ ) as a catalyst. The reaction mixture was stirred under an inert nitrogen atmosphere at room temperature for $12 \mathrm{~h}$. The solvent was evaporated and the residue treated with water and extracted with $\mathrm{CH}_{2} \mathrm{Cl}_{2}$. The organic layer was washed with water and dried over $\mathrm{MgSO}_{4}$. Complex 3 was precipitated by slow diffusion of pentane into a $\mathrm{CH}_{2} \mathrm{Cl}_{2}$ solution of the crude product. The complex was finally crystallized by slow evaporation of a concentrated $\mathrm{CH}_{2} \mathrm{Cl}_{2}$ solution (reddish-brown crystals, $m=45 \mathrm{mg}$, yield $=30 \%) .{ }^{1} \mathrm{H}$ NMR $\left(\mathrm{CDCl}_{3}\right) \delta 1.91$ (br, $\left.18 \mathrm{H}, \mathrm{CH}_{3}\right), 2.40\left(\mathrm{~m}, 4 \mathrm{H}, \mathrm{CH}_{2}\right), 7.44(\mathrm{~m}, 12 \mathrm{H}, \mathrm{CH}), 7.82(\mathrm{~m}, 8 \mathrm{H}$, $\mathrm{CH}) ;{ }^{13} \mathrm{C} \mathrm{NMR}\left(\mathrm{CDCl}_{3}\right) \delta 13.6,15.5,122.4,128.8,129.0,131.4$, 133.3, 133.5; ${ }^{31} \mathrm{P} \mathrm{NMR}\left(\mathrm{CDCl}_{3}\right) \delta 41.2\left(\mathrm{~s}, 2 \mathrm{P}, J_{\mathrm{P}-\mathrm{Pt}}=2298 \mathrm{~Hz}\right)$; IR (ATR): $2092 \mathrm{~cm}^{-1} \quad\left(\nu_{\mathrm{C} \equiv \mathrm{C}}\right)$; HRMS (ESI): $\mathrm{m} / \mathrm{z}$ calcd for $\mathrm{C}_{48} \mathrm{H}_{42} \mathrm{P}_{2} \mathrm{~S}_{8}{ }^{194} \mathrm{Pt} 1130.0148$. Found: 1130.0148 .

Complex 4 trans-Pt $\left(\mathbf{P P h}_{3}\right)_{2}\left(\mathbf{C} \equiv \mathbf{C M e}_{3} \mathbf{T T F}\right)_{2} \cdot$ cis-Pt $\left(\mathrm{PPh}_{3}\right)_{2} \mathrm{Cl}_{2}$ (100 mg, $0.13 \mathrm{mmol}$ ) and $\mathrm{HC} \equiv \mathrm{CMe}_{3} \mathrm{TTF}$ (68 mg, $0.26 \mathrm{mmol}$ ) were dissolved in a mixture of dry $\mathrm{CH}_{2} \mathrm{Cl}_{2}(10 \mathrm{~mL})$ and distilled $\mathrm{NEt}_{3}(5 \mathrm{~mL})$ inside a Schlenk tube. The solution was degassed and $\mathrm{CuI}$ (5 mg, $0.026 \mathrm{mmol}$ ) was added. After stirring for $48 \mathrm{~h}$ at room temperature, a red precipitate appeared. After 
Table 3 Crystallographic data

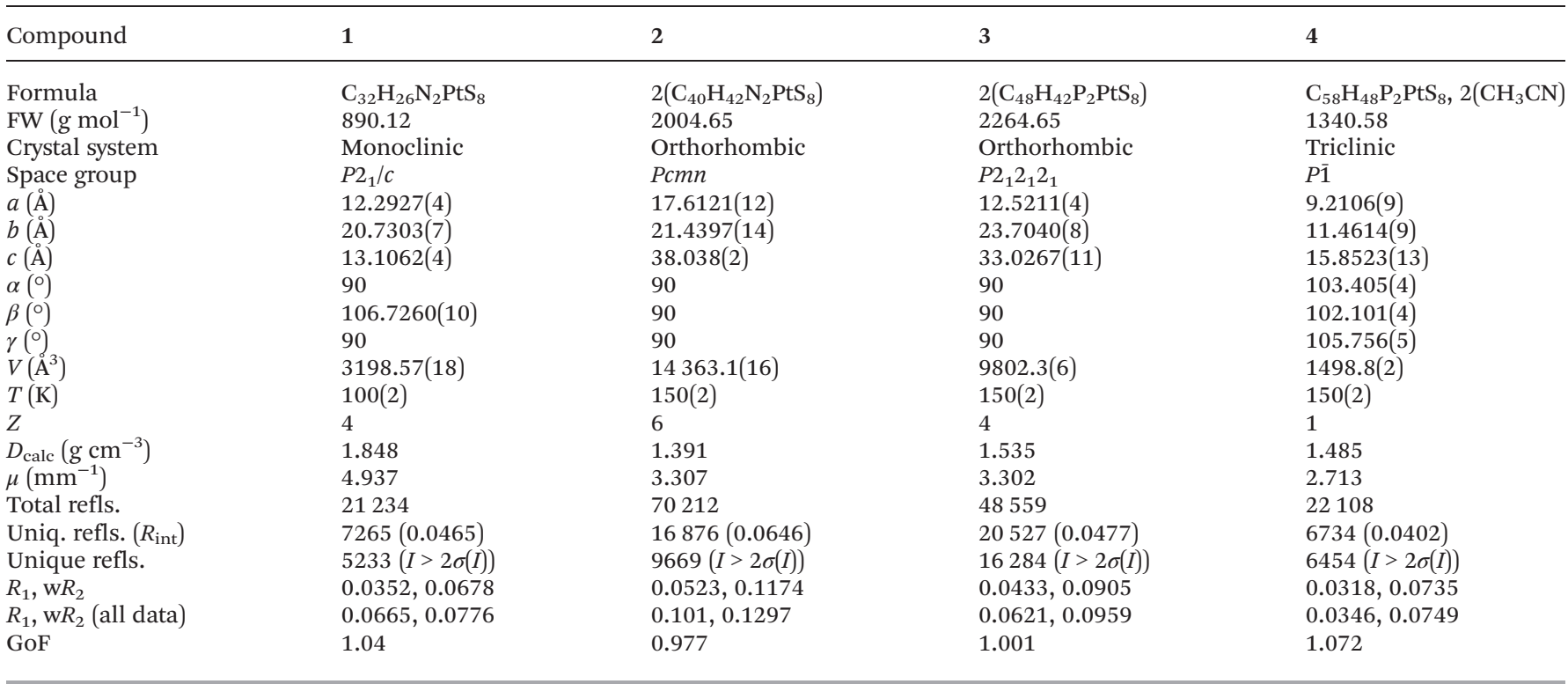

filtration, the red precipitate was washed with cold $\mathrm{CH}_{2} \mathrm{Cl}_{2}$. The material was dissolved in $\mathrm{CH}_{3} \mathrm{CN}$ and red crystals were grown by slow diffusion of diethyl ether ( $m=90 \mathrm{mg}, 57 \%$ yield). Due to its low solubility complex 4 could not be characterized by ${ }^{13} \mathrm{C}$ NMR. ${ }^{1} \mathrm{H}$ NMR $\left(\mathrm{CDCl}_{3}\right) \delta$ 1.90-1.95 (br, $18 \mathrm{H}$, $\left.\mathrm{CH}_{3}\right)$, 7.39-7.73 (m, 30H, CH); IR (ATR): $2086 \mathrm{~cm}^{-1}\left(\nu_{\mathrm{C} \equiv \mathrm{C}}\right)$; ${ }^{31} \mathrm{P}$ NMR $\left(\mathrm{CDCl}_{3}\right) \quad \delta 18$ (s). HRMS (ESI): $\mathrm{m} / \mathrm{z}$ calcd for $\mathrm{C}_{58} \mathrm{H}_{48} \mathrm{P}_{2} \mathrm{~S}_{8}{ }^{194} \mathrm{Pt} 1256.06183$. Found: 1256.0618 .

\section{X-Ray crystallography}

Details of the structural analyses for 1, 2, 3 and 4 are summarized in Table 3. X-Ray crystal structure determinations were performed on an APEXII Bruker-AXS diffractometer equipped with a CCD camera and a graphite-monochromated Mo K $\alpha$ radiation source $(\lambda=0.71073 \AA)$, from the Center de Diffractométrie (CDFIX), Université de Rennes 1, France. Structures were solved by direct methods using the SIR97 program, ${ }^{33}$ and then refined with full-matrix least-squares methods based on $F^{2}$ (SHELXL-97) ${ }^{34}$ with the aid of the WINGX program. ${ }^{35}$ For complexes 2 and 3, the contribution of the disordered solvents to the calculated structure factors was estimated following the $B Y P A S S$ algorithm, ${ }^{36}$ implemented as the SQUEEZE option in PLATON. ${ }^{37}$ A new data set, free of solvent contribution, was then used in the final refinement. All non-hydrogen atoms were refined with anisotropic atomic displacement parameters. $\mathrm{H}$ atoms were finally included in their calculated positions.

\section{Computational details}

Density functional theory ${ }^{38}$ calculations were performed with the hybrid Becke-3 parameter exchange functional ${ }^{39}$ and the Lee-Yang-Parr nonlocal correlation functional ${ }^{40}$ (B3LYP) implemented in the Gaussian 03 (revision D.02) program suite $^{41}$ using the LANL2DZ basis set ${ }^{42}$ with the default convergence criteria implemented in the program. The figures were generated with Molekel 4.3. ${ }^{43}$ Computational details are provided as ESI. $†$

\section{Acknowledgements}

The authors thank the CINES (Montpellier, France) for allocation of computing time.

\section{References}

1 D. Lorcy, N. Bellec, M. Fourmigué and N. Avarvari, Coord. Chem. Rev., 2009, 253, 1398-1438.

2 M. Shatruk and L. Ray, Dalton Trans., 2010, 39, 1110511121.

3 (a) D. Canevet, M. Sallé, G. Zhang, D. Zhang and D. Zhu, Chem. Commun., 2009, 2245-2269; (b) J.-Y. Balandier, M. Chas, S. Goeb, P. I. Dron, D. Rondeau, A. Belyasmine, N. Gallego and M. Sallé, New J. Chem., 2011, 35, 165-168; (c) J.-Y. Balandier, M. Chas, P. I. Dron, S. Goeb, D. Canevet, A. Belyasmine, M. Allain and M. Sallé, J. Org. Chem., 2010, 75, 1589-1599.

4 (a) G. Cosquer, F. Pointillart, Y. le Gal, S. Gohlen, O. Cador and L. Ouahab, Chem.-Eur. J., 2011, 17, 12502-12511; (b) F. Pointillart, Y. le Gal, S. Gohlen, O. Cador and L. Ouahab, Chem.-Eur. J., 2011, 17, 10397-10404; (c) F. Pointillart, A. Bourdolle, T. Cauchy, O. Maury, Y. Le Gal, S. Golhen, O. Cador and L. Ouahab, Inorg. Chem., 2012, 51, 978-984; (d) F. Pointillart, T. Cauchy, Y. Le Gal, S. Golhen, O. Cador and L. Ouahab, Chem. Commun., 2010, 46, 4947-4949.

5 (a) J. Qin, C.-X. Qian, N. Zhou, R.-M. Zhu, Y.-Z. Li, J.-L. Zuo and X.-Z. You, Eur. J. Inorg. Chem., 2012, 2, 234-245; (b) J. Xiong, W. Liu, Y. Wang, L. Cui, Y.-Z. Li and J.-L. Zuo, Organometallics, 2012, 31, 3938-3946; (c) J. Xiong, G.-N. Li, 
L. Sun, Y.-Z. Li, J.-L. Zuo and X.-Z. You, Eur. J. Inorg. Chem., 2011, 33, 5173-5181; (d) G.-N. Li, T. Jin, L. Sun, J. Qin, D. Wen, J.-L. Zuo and X.-Z. You, J. Organomet. Chem., 2011, 696, 3076-3085; (e) J. Qin, L. Hu, G.-N. Li, X.-S. Wang, Y. Xu, J.-L. Zuo and X.-Z. You, Organometallics, 2011, 30, 2173-2179.

6 A. Vacher, F. Barrière, T. Roisnel and D. Lorcy, Chem. Commun., 2009, 7200-7202.

7 A. Miyazaki, Y. Ogyu, F. Justaud, L. Ouahab, T. Cauchy, J.-F. Halet and C. Lapinte, Organometallics, 2010, 29, 46284638.

8 A. Vacher, F. Barrière, T. Roisnel, L. Piekara-Sady and D. Lorcy, Organometallics, 2011, 30, 3570-3578.

9 J. Nishijo, K. Judai and N. Nishi, Inorg. Chem., 2011, 50, 3464-3470.

10 S. C. Jones, V. Coropceanu, S. Barlow, T. Kinnibrugh, T. Timofeeva, J.-L. Brédas and S. R. Marder, J. Am. Chem. Soc., 2004, 126, 11782-11783.

11 D. Osella, R. Gobetto, C. Nervi, M. Ravera, R. D'amato and M. V. Russo, Inorg. Chem. Commun., 1998, 1, 239-245.

12 Á. Díez, E. Lalinde, M. T. Moreno and S. Sánchez, Dalton Trans., 2009, 3434-3446.

13 K. Sonogashira, Y. Fujikura, T. Yatake, N. Toyoshima, S. Takahashi and N. Hagihara, J. Organomet. Chem., 1978, 145, 101-108.

14 (a) A. L. Sadowy, M. J. Ferguson, R. McDonald and R. R. Tykwinski, Organometallics, 2008, 27, 6321-6325; (b) C. A. Tolman, Chem. Rev., 1977, 77, 313-348.

15 (a) M. Hissler, W. B. Connick, D. K. Geiger, J. E. McGarrah, D. Lipa, R. J. Lachicotte and R. Eisenberg, Inorg. Chem., 2000, 39, 447-457; (b) A. Jakob, P. Ecorchard, K. Köhler and H. Lang, J. Organomet. Chem., 2008, 693, 3479-3489; (c) U. Siemeling, K. Bausch, H. Fink, C. Bruhn, M. Baldus, B. Angerstein, R. Plessow and A. Brockhinke, Dalton Trans., 2005, 2365-2374; (d) C. W. Chan, L. K. Cheng and C. M. Che, Coord. Chem. Rev., 1994, 132, 87-97; (e) F. Hua, S. Kinayyigit, A. A. Rachford, E. A. Shikhova, S. Goeb, J. R. Cable, C. J. Adams, K. Kirschbaum, A. A. Pinkerton and F. N. Castellano, Inorg. Chem., 2007, 46, 8771-8783.

16 C. J. Adams, S. L. James, X. Liu, P. R. Raithby and L. J. Yellowlees, J. Chem. Soc., Dalton Trans., 2000, 63-67.

17 V. W.-W. Yam, L.-P. Chan and T.-F. Lai, Organometallics, 1993, 12, 2197-2202.

18 J. E. Beves, E. C. Constable, C. E. Housecroft, M. Neuburger, S. Schaffner and E. J. Shardlow, Dalton Trans, 2007, 1593-1602.

19 S.-C. Chan, M. C. W. Chan, Y. Wang, C.-M. Che, K.-K. Cheung and N. Zhu, Chem.-Eur. J., 2001, 7, 4180-4190.

20 F. Hua, S. Kinayyigit, J. R. Cable and F. N. Castellano, Inorg. Chem., 2006, 45, 4304-4306.

21 (a) C. Goze, S.-X. Liu, C. Leiggener, L. Sanguinet, E. Levillain, A. Hauser and S. Decurtins, Tetrahedron, 2008, 64, 1345-1350; (b) C.-H. Xu, W. Sun, C. Zhang, C. Zhou, C.-J. Fang and C.-H. Yan, Chem.-Eur. J., 2009, 15, 87178721; (c) G. Zhang, D. Zhang, X. Guo and D. Zhu, Org. Lett., 2004, 6, 1209-1212; (d) S. Leroy-Lhez, J. Baffreau, L. Perrin,
E. Levillain, M. Allain, M.-J. Blesa and P. Hudhomme, J. Org. Chem., 2005, 70, 6313-6320; (e) X. Guo, D. Zhang, H. Zhang, Q. Fan, W. Xu, X. Ai, L. Fan and D. Zhu, Tetrahedron, 2003, 59, 4843-4850; $(f)$ H. Li, J. O. Jeppesen, E. Levillain and J. Becher, Chem. Commun., 2003, 846-847.

22 (a) B. Ventura, A. Barbieri, F. Barigelletti, J. B. Seneclauze, P. Retailleau and R. Ziessel, Inorg. Chem., 2008, 47, 70487058; (b) S.-C. Chan, M. C. W. Chan, Y. Wang, C.-M. Che, K.-K. Cheung and N. Zhu, Chem.-Eur. J., 2001, 7, 41804190; (c) R. Ziessel, J. B. Seneclauze, B. Ventura, A. Barbieri and F. Barigelletti, Dalton Trans., 2008, 1686-1688.

23 (a) R. Saha, M. A. Qaium, D. Debnath, M. Younus, N. Chawdhury, N. Sultana, G. Kociok-Köhn, L.-L. Ooi, P. R. Raithby and M. Kijima, Dalton Trans., 2005, 27602765; (b) T. L. Schull, J. G. Kushmerick, C. H. Patterson, C. George, M. H. Moore, S. K. Pollack and R. Shashidhar, J. Am. Chem. Soc., 2003, 125, 3202-3203; (c) R. D'Amato, A. Furlani, M. Colapietro, G. Portalone, M. Casboni, M. Falconieri and M. V. Russo, J. Organomet. Chem., 2001, 627, 13-22.

24 (a) J. E. McGarrah and R. Eisenberg, Inorg. Chem., 2003, 42, 4355-4365; (b) J. E. McGarrah, J. T. Hupp and S. N. Smirnov, J. Phys. Chem. A, 2009, 113, 6430-6436.

25 H. Spanggaard, J. Prehn, M. B. Nielsen, E. Levillain, M. Allain and J. Becher, J. Am. Chem. Soc., 2000, 122, 9486-9494.

26 (a) M. N. Jayaswal, H. N. Peindy, F. Guyon, M. Knorr, N. Avarvari and M. Fourmigué, Eur. J. Inorg. Chem., 2004, 2646-2651; (b) F. Guyon, M. N. Jayasal, H. N. Peindy, A. Hameau, M. Knorr and N. Avarvari, Synth. Met., 2005, 151, 186-190.

27 M. Iyoda, M. Hasegawa and Y. Miyake, Chem. Rev., 2004, 104, 5085-5113.

28 M. Fourmigué and Y.-S. Huang, Organometallics, 1993, 12, 797-802.

29 (a) F. Barrière and W. E. Geiger, J. Am. Chem. Soc., 2006, 128, 3980-3989; (b) W. E. Geiger and F. Barrière, Acc. Chem. Res., 2010, 43, 1030-1039; (c) F. Barrière, R. J. Le Suer and W. E. Geiger, Electrochemical advances using fluoroarylborate anion supporting electrolytes, in Trends in Molecular Electrochemistry, ed. A. J. L. Pombeiro and C. Amatore, Fontis Media, Marcel Dekker, 2004, ch. 13, pp. 413-444; (d) F. Barrière, N. Camire, W. E. Geiger, U. T. Mueller-Westerhoff and R. Sanders, J. Am. Chem. Soc., 2002, 124, 72627263.

30 The SOMOs of $2^{+\cdot}$ and $4^{+\cdot}$ have the symmetry of the HOMO -1 orbitals in 2 and 4 . Note that the energy gap between the HOMO and the HOMO -1 is very small (0.06 $\mathrm{eV}$ for 2 and $0.07 \mathrm{eV}$ for $\mathbf{4}$ ).

31 (a) K. A. Z. Jensen, Anorg. Chem., 1936, 229, 236; (b) R. D. Gillard and M. F. Pilbrow, J. Chem. Soc., Dalton Trans., 1974, 21, 2320-2325.

32 B. H. Abdullah, M. A. Abdullah, S. A. Al-Jibori and T. A. K. Al-Allaf, Asian J. Chem., 2007, 19, 1334-1340.

33 A. Altomare, M. C. Burla, M. Camalli, G. Cascarano, C. Giacovazzo, A. Guagliardi, A. G. G. Moliterni, G. Polidori and R. Spagna, J. Appl. Crystallogr., 1999, 32, 115-119. 
34 G. M. Sheldrick, Acta Crystallogr., Sect. A: Fundam. Crystallogr., 2008, 64, 112-122.

35 L. J. Farrugia, J. Appl. Crystallogr., 1999, 32, 837-838.

36 P. van der Sluis and A. L. Spek, Acta Crystallogr., Sect. A: Fundam. Crystallogr., 1990, 46, 194-201.

37 A. L. Spek, Acta Crystallogr., Sect. D: Biol. Crystallogr., 2009, 65, 148-155.

38 (a) P. Hohenberg and W. Kohn, Phys. Rev., 1964, 136, B864; (b) R. G. Parr and W. Yang, Density-Functional Theory of Atoms and Molecules, Oxford University Press, Oxford, UK, 1989.

39 (a) A. D. Becke, Phys. Rev. A, 1988, 38, 3098-3100;

(b) A. D. Becke, J. Chem. Phys., 1993, 98, 1372-1377;

(c) A. D. Becke, J. Chem. Phys., 1993, 98, 5648-5652.

40 C. Lee, W. Yang and R. G. Parr, Phys. Rev. B: Condens. Matter, 1988, 37, 785-789.

41 M. J. Frisch, G. W. Trucks, H. B. Schlegel, G. E. Scuseria, M. A. Robb, J. R. Cheeseman, J. A. Montgomery Jr., T. Vreven, K. N. Kudin, J. C. Burant, J. M. Millam, S. S. Iyengar, J. Tomasi, V. Barone, B. Mennucci, M. Cossi, G. Scalmani, N. Rega, G. A. Petersson, H. Nakatsuji, M. Hada, M. Ehara,
K. Toyota, R. Fukuda, J. Hasegawa, M. Ishida, T. Nakajima, Y. Honda, O. Kitao, H. Nakai, M. Klene, X. Li, J. E. Knox, H. P. Hratchian, J. B. Cross, V. Bakken, C. Adamo, J. Jaramillo, R. Gomperts, R. E. Stratmann, O. Yazyev, A. J. Austin, R. Cammi, C. Pomelli, J. W. Ochterski, P. Y. Ayala, K. Morokuma, G. A. Voth, P. Salvador, J. J. Dannenberg, V. G. Zakrzewski, S. Dapprich, A. D. Daniels, M. C. Strain, O. Farkas, D. K. Malick, A. D. Rabuck, K. Raghavachari, J. B. Foresman, J. V. Ortiz, Q. Cui, A. G. Baboul, S. Clifford, J. Cioslowski, B. B. Stefanov, G. Liu, A. Liashenko, P. Piskorz, I. Komaromi, R. L. Martin, D. J. Fox, T. Keith, M. A. Al-Laham, C. Y. Peng, A. Nanayakkara, M. Challacombe, P. M. W. Gill, B. Johnson, W. Chen, M. W. Wong, C. Gonzalez and J. A. Pople, GAUSSIAN 03 (Revision D.02), Gaussian, Inc., Wallingford CT, 2004.

42 (a) W. R. Wadt and P. J. Hay, J. Chem. Phys., 1985, 82, 284-298;

(b) P. J. Hay and W. R. Wadt, J. Chem. Phys., 1985, 82, 299-310.

43 P. Flükiger, H. P. Lüthi, S. Portmann and J. Weber, MOLEKEL 4.3, Swiss Center for Scientific Computing, Manno (Switzerland), 2000. 